\title{
Effect of Crop Establishment and Nutrient Management on Growth Parameter and Nutrient Uptake in Maize Wheat System of Northern Plains of IGP
}

\author{
Lakhapati Singh*, U.P. Singh and M.K. Singh \\ Department of Agronomy, Institute of Agricultural Sciences, \\ Banaras Hindu University Vanarasi, India \\ *Corresponding author
}

\section{A B S T R A C T}

\section{Keywords}

Crop establishment methods,

Conservation agriculture, Maizewheat system, Nutrient uptake and residue

\section{Article Info}

Accepted:

04 February 2019

Available Online:

10 March 2019
A field experiment was conducted 2013-14 and 2014-15 at Agricultural Research Farm, Institute of Agricultural Sciences, Banaras Hindu University is situated in the South-East direction. The geographical situation of the farm lies at $25^{\circ} 18^{\prime} \mathrm{N}$ latitude and $83^{\circ} 31^{\prime} \mathrm{E}$ longitude at an altitude of 75.7 meters above the mean sea level in the Northern Gangetic Alluvial plains and soil textural class is sandy clay loam soil to study the effect of crop establishment method and nutrient management in maize wheat system. The experiment consisted of four crop establishment method [ $\mathrm{C}_{1}$-Conventional/Farmers Practice (FP), $\mathrm{C}_{2^{-}}$ Improved over (FP), $\mathrm{C}_{3^{-}}$Partial Conservation Agriculture (CA), $\mathrm{C}_{4^{-}}$Full Conservation Agriculture (CA)] as main plot treatment and three nutrient management $\left(\mathrm{N}_{1}\right.$ Farmer fertilize practice (FFP), $\mathrm{N}_{2}$ Recommended dose of fertilizer (RDF), $\mathrm{N}_{3}$ Site specific nutrient management (SSNM) as sub plot treatment laid out in split plot design with three replication. Significant improvement in the growth character and nutrient uptake was observed with $\mathrm{C}_{4}$ as per crop growth stage and nutrient uptake which was at par with $\mathrm{C}_{3}$ treatment. Among nutrient management treatment $\left(\mathrm{N}_{3}\right)$ resulted in higher growth parameter nutrient uptake which was at par with recommended dose of fertilizer $\left(\mathrm{N}_{2}\right)$.

\section{Introduction}

Maize (Zea mays L.) is one of the most important crops in world's agricultural economy grown over an area of 159 million hectares with a total production of 817 million tonnes. India ranks fourth in area and sixth in production of maize. In India, it is an important cereal crop next only to rice and wheat with acreage of around $8.36 \mathrm{~m}$ ha and production of 16.72 million tonnes with highest per day productivity. As it has yield potential far higher than any other cereal, it is commonly known as the 'Miracle crop' or the 'Queen of Cereals' (Anonymous, 2011). The consumption pattern for maize produced in India at present includes poultry feed (52\%), human food (24\%), animal feed (11\%), starch $(11 \%)$, brewery $(1 \%)$ and seed $(1 \%)$ (Sain Dass et al., 2007). As per the estimated 
projection, India may have to produce 55 million tonnes of maize to meet its requirement for human consumption, poultry, piggery, pharma industry and fodder by 2030.

Among food crops, maize and wheat are two important cereals contributing to food and nutritional security at the global level. Maizewheat (MW) cropping systems mainly practiced in Indo- Gangetic Basin is the fifth major crop sequence of India being practiced on about $1.80 \mathrm{~m}$ ha area (Timsina et al., 2010) and contributes $2.4 \%$ to the national food basket (Jat et al., 2011). The unprecedented demands of the spiraling population are putting a considerable strain on the natural resources. In the past the focus was on increasing food production to attain selfsufficiency, but indiscriminate use of resources not only led to the reduction in total factor productivity but also resulted in environmental degradation (Yadav, 2003). The focus has now shifted to sustainable production technologies and resource efficient cropping systems. Among the various inputs, water and fertilizer (nutrients) are considered as the two key inputs making maximum contribution to crop productivity.

Sustaining soil organic carbon (SOC) is of primary importance in terms of cycling plant nutrients and improving the soils' physical, chemical and biological properties. SOC is an important index of soil quality because of its relationship with crop productivity (Lal, 1997). Singh et al., (2011) reported that the different tillage and residue management practices could potentially lead to significant difference in soil organic carbon (SOC) content, bulk density and irrigation water requirement. Inclusion of partial crop residue remarkably improved SOC content by $12.60 \%$, bulk density by $6.27 \%$ and reduced irrigation water by $18.88 \%$ over conventional till (CT). Raised fresh bed being statistically at par with CT resulted in significant increase in mean grain yield by 20.8 and $19.6 \%$ (kharif) and 22.5 and $15.3 \%$ (rabi), respectively, over the zero tillage with residue. A number of field studies have been conducted to determine the effects of varying tillage practices on the soil surface residue cover, soil water distribution and maize production but more efficient moisture use and improved soil physical properties associated with zero tillage are often cited as reasons for the success of zero tillage systems on well drained soils (Griffith et al., 1986). Compared to CT, minimum till with residue (MTR) proved to be a promising alternative soil management practice to improve and sustain higher yields of rainfed maize in a sub humid subtropical climate. This practice also improved soil quality by increasing organic carbon, aggregation, infiltration rate and soil water retention, as well as decreasing bulk density near the soil surface (Ghuman and Sur, 2001). By reducing tillage, farmers save labour and money that would otherwise be invested in implements and tractor power (Smart and Bradford, 1999). In addition to the economic benefits, CA can improve soil health by increasing soil organic matter and biological activity as well as macro porosity, water infiltration and the amount of plant-available soil water (Wright et al., 2005). In addition to decreasing soil temperature and evaporation, a permanent surface residue layer provides a barrier against rapid water runoff (Findeling, 2001).

Conservation agriculture, i.e. residue retention, zero tillage and crop rotation improves water use efficiency, decreases soil erosion and temperature, improves soil quality and increases yields (Lichter et al., 2008).

Soil moisture content in no-till systems is often higher than in conventional tillage (Ussiri et al., 2009). Bakht et al., (2009) found that returning of crop residues, application of fertilizer $\mathrm{N}$ and involvement of legumes in 
crop rotation greatly improves the $\mathrm{N}$ economy of the cropping systems and enhances crop productivity through additional $\mathrm{N}$ and other benefits in low N soils. Sustaining soil organic carbon (SOC) is of primary importance in terms of cycling plant nutrients and improving the soil physical, chemical and biological properties. SOC is an important index of soil quality because of its relationship with crop productivity (Lal, 1997).

Returning of straw can increase the porosity of soil. Through the analysis of affecting force, it can be concluded that interaction of soil tillage and straw is the most important factor to soil porosity, while the controlling factor to noncapillary porosity was soil tillage treatment. (Kumar et al., 2013) showed that zero-tillage improved the operational field capacity by $81 \%$, specific energy by $17 \%$ and the energy usage efficiency by $13 \%$ as compared to the conventional tillage and these practices are viable options for the farmers not only in terms of energy and time efficiency but also for attaining higher productivity and profitability.

The CA based resource conservation technologies (RCTs) involve permanent raised bed (PRB), zero or minimum-tillage with direct seeding using seed-cum-fertilizer drill and bed planting innovations in residue management to avoid straw burning and crop diversification (Singh et al., 2011).

Farm mechanization plays a vital role for the success of CA based RCTs in different agroecologies and socioeconomic farming groups. It ensures timeliness, precision and quality of field operations; reduces production cost; saves labor; reduces weather risk in the changing climatic scenarios; improves productivity, environmental quality, sustainability and generates rural employment on on-farm and off-farm activities (Saharawat et al., 2011).

\section{Materials and Methods}

\section{Experimental site}

A field experiment was conducted at Agricultural Research Farm, Institute of Agricultural Sciences, Banaras Hindu University is situated at distance of about 10 $\mathrm{km}$ from Varanasi railways station in the South-East direction and soil texture is sandy clay loam. The geographical situation of the farm lies at $25^{\circ} 18^{\prime} \mathrm{N}$ latitude and $83^{\circ} 31^{\prime} \mathrm{E}$ longitude at an altitude of 75.7 meters above the mean sea level in the Northern Gangetic Alluvial plains. The location of the experimental site remained same during both the years of the investigation. The field of the experimental site represented ideal spatial units in respect of textural make up and uniform fertility status.

\section{Crop and climate}

Climatologically Varanasi district enjoys a subtropical climate and is subjected to extremes of weather conditions i.e. extremely hot summer and cold winter. This region falls in semi-arid to sub-humid type of climate. Normally the period for the onset of monsoon in this domain is third week of June and it lasts upto the end of September or sometimes extends upto the first week of October. The area also experiences some winter shower due to cyclonic rains during December to February. The period between March to May is generally dry. Long term average (over 1941 to 1996) of annual rainfall for this region amounts to $1081.5 \mathrm{~mm}$ of which $944.5 \mathrm{~mm}$ (87.33 per cent) is received during the monsoon or rainy season (June to September) and $137.0 \mathrm{~mm}$ (12.67 per cent) during post monsoon season or post rainy season. The mean annual Potential Evapo-transpiration (PET) is $1525 \mathrm{~mm}$. The temperature begins to rise from middle of February and reaches its maximum by May-June (mean maximum 
$39^{\circ} \mathrm{C}$ ). But it has tendency to decrease from July onwards and eventually touches minimum in December-January (mean minimum $9.3^{\circ} \mathrm{C}$ ). The hottest and coolest period of the year is end of May and first half of January, respectively. The maximum temperature usually fluctuates between $22^{\circ} \mathrm{C}$ to $40.7^{\circ} \mathrm{C}$ while minimum temperature varies from 8.6 to $29.9^{\circ} \mathrm{C}$. Occasionally extreme of minimum and maximum temperature variations are realized.

\section{Treatment details and field layout}

The experiment consisted of four crop establishment method $\left[\left(\mathrm{C}_{1^{-}}\right.\right.$ Conventional/Farmers Practice (FP), Conventional till ridge seeding of maize, rotavator till broadcast seeding of wheat, remove all maize residue, remove wheat residue. $\mathrm{C}_{2^{-}}$Improved over (FP), Conventional till ridge seeding of maize, rotavator till broadcast seeding of wheat, conventional till Green gram, remove all maize residue, remove wheat residue, incorporate all residues of Green gram. $\mathrm{C}_{3}$ Partial Conservation Agriculture (CA) Both maize and wheat on permanent beds, retain wheat residue $(45 \mathrm{~cm})$, retain $50 \%$ maize straw. $\mathrm{C}_{4}$ - Full Conservation Agriculture (CA) as main plot treatment and three nutrient management $\left[\left(\mathrm{N}_{1}\right.\right.$ Farmer fertilize practice (FFP), Conducted a survey in the local area of the experimental site and collected data regarding fertilizer use in maize and wheat from fifty farmers, use average value as farmer fertilizer practice (FFP). Farmers used $\mathrm{N}, \mathrm{P}_{2} \mathrm{O}_{5}$ and $\mathrm{K}_{2} \mathrm{O}$, for maize 91:48:0 kg ha- ${ }^{-1}$. $\mathrm{N}_{2}$ Recommended dose of fertilizer (RDF). The fertilizer dose for maize $(120: 60: 60 \mathrm{~kg}$ ha-1) recommended by state agriculture department. $\mathrm{N}_{3}$ Site specific nutrient management (SSNM) (use Nutrient Expert DSS for maize), Use nutrient expert (NE) decision support tool for maize, the fertilizer dose for maize during 2013-14 N, $\mathrm{P}_{2} \mathrm{O}_{5}$ and
$\mathrm{K}_{2} \mathrm{O}$ 117:59:81 and during 2014-15 N, $\mathrm{P}_{2} \mathrm{O}_{5}$ and $\mathrm{K}_{2} \mathrm{O}$ 107:55:65. NE is computer-based decision support tool developed to assist local experts to quickly formulate fertilizer guidelines for maize. The software is based on the principles of site-specific nutrient management (SSNM). NE estimates the attainable yield and yield response to fertilizer from site information using decision rules developed from on-farm trials. NE uses: (a) Characteristics of the growing environment: water availability (irrigated, fully rainfed, rainfed with supplemental irrigation) and any occurrence of flooding or drought. (b) Soil fertility indicators: soil texture, soil color and organic matter content, soil test for P or K (if any), historical use of organic materials (if any), problem soils (if any). (c) Crop sequence in the farmer's cropping pattern. (d) Crop residue management and fertilizer inputs, and (e) Farmer's current yields.] as sub plot treatment laid out in split plot design with three replications. The size of the plot $8.0 \mathrm{X}$ $7.0 \mathrm{~m}$ was adopted in field experiment.

\section{Plant height (cm)}

The plant height of five tagged plants were measured at 30 days intervals and at harvest from the ground level up to the base of the fully opened leaf at pre-tasseling and up to the base of tassel at post-tasseling stage.

\section{Leaf area $\left(\mathrm{cm}^{2} /\right.$ plant $)$}

The leaf area of maize was measured by (Model LICOR-3100) leaf area meter. The area of each of the leaves on a plant was added (summed) to obtain the leaf area per plant.

\section{Leaf area index}

The maize crop leaves were stripped off from their base from the collected samples for dry matter accumulation. Total area of all the leaves was determined with the help of leaf 
area meter (Model LI-COR-3100). LAI was expressed as the ratio of leaf area to the land area occupied by the plant and the leaf area index/plant was calculated by using the following formula:

Leaf area index $(\mathrm{LAI})=$

Total leaf area/plant $\left(\mathrm{cm}^{2}\right)$

Ground area occupied/plant $\left(\mathrm{cm}^{2}\right)$

\section{Dry matter accumulation (g/plant)}

Five plants from sampling rows uprooted and above ground portions were cut for observations.

The sampled plants were dried in electric oven at $70^{\circ} \mathrm{c}$ till it attained constant weight. Dry weight was expressed in $\mathrm{g} / \mathrm{plant}$.

\section{Nitrogen content and uptake}

$\mathrm{N}$ content (\%) in grain and straw was determined by modified Kjeldahl method (Prasad et al., 2006). N uptake was calculated by using the following expression:

$\mathrm{N}$ uptake $(\mathrm{kg} / \mathrm{ha})$ in grain/stover $=[\% \mathrm{~N}$ in grain/ stover X grain/stover yield (kg/ha)]

Total uptake of $\mathrm{N}(\mathrm{kg} / \mathrm{ha})=\mathrm{N}$ uptake in grain $+\mathrm{N}$ uptake in stover

\section{Phosphorus content and uptake}

Phosphorus content in grain and straw was determined by vanadomolybdophosphoric acid yellow colour method (Prasad et al., 2006). Total P uptake (kg/ha) was calculated by following expression:

$\mathrm{P}$ uptake $(\mathrm{kg} / \mathrm{ha})$ in grain $/$ stover $=[\% \mathrm{P}$ in grain/straw X grain/stover yield ( $\mathrm{kg} / \mathrm{ha})$ ]

Total uptake of $\mathrm{P}(\mathrm{kg} / \mathrm{ha})=\mathrm{P}$ uptake in grain $+\mathrm{P}$ uptake in stover

\section{Potassium content and uptake}

Potassium content in grain and stover was determined by flame photometer (Prasad et al., 2006). Potassium uptake was calculated by multiplying $\mathrm{K}$ content with the dry matter yield

$\mathrm{K}$ uptake $(\mathrm{kg} / \mathrm{ha})$ in grain $/$ stover $=[\% \mathrm{~K}$ in grain/ stover X grain/stover yield (kg/ha)]

Total uptake of $\mathrm{K}(\mathrm{kg} / \mathrm{ha})=\mathrm{K}$ uptake in grain $+\mathrm{K}$ uptake in stover.

\section{Results and Discussion}

The different growth parameters, viz. plant height, dry matter accumulation and leaf area index of maize were influenced significantly due to crop establishment method in both the year of study. The growth parameters of maize were significantly higher under full conservation agriculture than farmer practice, this might be due better root growth (Aggarwal et al., 2006), which might helped in better soil moisture extraction during dry periods and maintained the plant vigour. The residue retention and incorporation significantly improved all the growth parameters than no-residue, this might be due to residue retention and incorporation improve the physical environment in the soil; more available soil moisture and nutrients, moderate the soil temperature and reduce the evaporation losses from surface soil (Table 13).

Ram (2006) also reported higher values of plant height, dry matter accumulation and LAI under permanent bed with residue than noresidue under both ZT and CT practices. Similar results were also reported by (Tolk et al., 1999). The growth parameters of wheat crop were similar under full conservation agriculture. However, marginally higher values of growth parameters were recorded during 2014-15 than 20013-14, it might be due 
to better crop establishment of crop resulted congenial weather conditions at the time of sowing.

The growth parameters were significantly higher under full conservation agriculture with farmer practice, this might be due to better soil health and micro-environment created by continuous adoption of these environment friendly and resource conserving practices. (Wilhelm 1989) also reported higher LAI and better growth of the crop under no-till treatments. Yadav et al., (2005) also reported marginally higher growth parameters under ZT than CT. Since maize and wheat crops are heavy feeder of all essential nutrients in general.

The growth parameter of maize and wheat significantly higher with SSNM over FP at par with SR, it seems that SSNM-based balanced dose provided nutrient as per the crop requirement, hence better plant growth was observed with SSNM. Similar results was reported by (Kumar et al., 2014) and they observed that the dry-matter accumulation and leaf-area index were significantly higher with site-specific nutrient management (SSNM) over the recommended dose of fertilizer (RDF) under conservation agriculture.

\section{Nutrient uptake}

Crop establishment method brought significant differences in the nutrient uptake by the maize. The higher mean total N, P and $\mathrm{K}$ uptake under full $\mathrm{CA}\left(\mathrm{CE}_{4}\right)$ by the maizewheat cropping system might be due to better root growth, leading to more extraction of nutrient from soil, lower weed infestation and better performance of crops particularly by maize under water logging condition, thus all these factors might have contributed to higher uptakes of nutrients under full CA than CT. (Singh et al., 2007) reported that total $\mathrm{N}$ uptake by maize was highest $(67.46 \mathrm{~kg} / \mathrm{ha})$ under bed planting than flat sowing of maize.
(Nema et al., 1996) also reported higher uptake of $\mathrm{N}, \mathrm{P}$ and $\mathrm{K}$ by maize under ridge and furrow system of planting. Singh et al., (2007) reported that minimum tillage recorded the highest $\mathrm{N}$ uptake by weeds, significantly lowest under CT-bed planting systems. Similarly, Chopra and Angiras (2008) also revealed that compared to $\mathrm{ZT}, \mathrm{CT}$ and raised beds resulted significantly higher uptake of NPK by maize $(18.1,25.0$ and $20.2 \%$ by the former and 16.1, 32.2 and $16.7 \%$ respectively by the later method and lower depletion of these nutrients by weeds (13.5, 15.6 and 10.8 $\%$ by the former and $30.3,30.3$ and $29.0 \%$, respectively by the latter method. However, the maximum $\mathrm{N}, \mathrm{P}$ and $\mathrm{K}$ uptake were recorded under $\mathrm{ZT}$ with residue (full $\mathrm{CA}$ ) applications, this might be due to addition of nutrients through residue, improved physical environment favorable for better microbial activity that might helped in mineralization resulting better availability of nutrients (macro and micro) to crops and thus increased the uptake under these treatments (Behera et al., 2007). Residue retention suppress the growth of weeds, increased the moisture availability and moderate the soil temperature, so all these factor may overcome the effect the zero tillage practices without residue applications. Application of organic sources released plant nutrients in slow manner throughout the crop growth period causing better uptake of nutrients by crop plants. Thus, it increased the biomass accumulation which ultimately increased the grain yield of crops. A similar result was also reported by (Patra et al., 2004), the maize crops efficiently utilized the applied as well as soil $\mathrm{N}$ and $\mathrm{P}$ under bed planting than flat planting. ZT practices resulted higher nutrient balance in the soil than CT practices, this might be due to poor growth of the both maize and wheat crops under these conditions reflected in terms of lower uptake, and also addition of considerable quantities of biomass through root stables of crops and weed biomass under ZT practices (Table 4). 
Table.1 Effect of crop establishment and nutrient management on plant height $(\mathrm{cm})$ at different growth stages of maize

\begin{tabular}{|c|c|c|c|c|c|c|c|c|}
\hline \multirow[t]{2}{*}{ Treatments } & \multicolumn{2}{|c|}{30 DAS } & \multicolumn{2}{|c|}{60 DAS } & \multicolumn{2}{|c|}{90 DAS } & \multicolumn{2}{|c|}{ At harvest } \\
\hline & 2013 & 2014 & 2013 & 2014 & 2013 & 2014 & 2013 & 2014 \\
\hline \multicolumn{9}{|c|}{ Crop establishment methods $(C)$} \\
\hline $\mathrm{C1}$ & 57.73 & 61.49 & 174.5 & 176.05 & 192.3 & 193.99 & 200.0 & 201.43 \\
\hline $\mathrm{C2}$ & 63.19 & 67.92 & 178.9 & 180.93 & 195.4 & 197.09 & 202.0 & 203.38 \\
\hline C3 & 65.65 & 75.37 & 197.6 & 198.88 & 210.3 & 212.05 & 217.7 & 219.30 \\
\hline $\mathrm{C4}$ & 71.27 & 79.82 & 203.1 & 204.00 & 213.3 & 214.41 & 220.7 & 222.19 \\
\hline SEm \pm & 3.17 & 2.60 & 5.29 & 5.09 & 4.25 & 4.31 & 4.40 & 4.41 \\
\hline $\operatorname{LSD}(\mathbf{P}=\mathbf{0 . 0 5})$ & NS & 8.98 & 18.30 & 17.62 & 14.71 & 14.91 & 15.23 & 15.26 \\
\hline \multicolumn{9}{|c|}{ Nutrient management(N) } \\
\hline N1 & 64.08 & 68.10 & 178.5 & 180.90 & 194.7 & 195.91 & 200.6 & 202.36 \\
\hline $\mathbf{N} 2$ & 63.83 & 71.49 & 191.6 & 192.21 & 205.5 & 207.22 & 213.3 & 214.88 \\
\hline $\mathbf{N 3}$ & 65.46 & 73.86 & 195.5 & 196.79 & 208.3 & 210.02 & 216.4 & 217.49 \\
\hline SEm \pm & 1.23 & 1.20 & 4.21 & 3.03 & 3.79 & 2.76 & 4.17 & 3.14 \\
\hline $\operatorname{LSD}(\mathbf{P}=\mathbf{0 . 0 5})$ & NS & 3.59 & 12.63 & 9.08 & 11.36 & 8.28 & 12.49 & 9.40 \\
\hline
\end{tabular}


Int.J.Curr.Microbiol.App.Sci (2019) 8(3): 305-317

Table.2 Effect of crop establishment methods and nutrient management on leaf area index at different growth stages of maize

\begin{tabular}{|c|c|c|c|c|c|c|c|c|}
\hline \multirow[t]{2}{*}{ Treatments } & \multicolumn{2}{|c|}{30 DAS } & \multicolumn{2}{|c|}{60 DAS } & \multicolumn{2}{|c|}{90 DAS } & \multicolumn{2}{|c|}{ At harvest } \\
\hline & 2013 & 2014 & 2013 & 2014 & 2013 & 2014 & 2013 & 2014 \\
\hline \multicolumn{9}{|c|}{ Crop establishment methods $(C)$} \\
\hline $\mathrm{C1}$ & 0.84 & 0.88 & 3.22 & 3.30 & 3.34 & 3.41 & 2.03 & 2.11 \\
\hline $\mathrm{C2}$ & 0.85 & 0.90 & 3.25 & 3.33 & 3.39 & 3.46 & 2.11 & 2.19 \\
\hline C3 & 0.90 & 0.97 & 3.46 & 3.54 & 3.60 & 3.68 & 2.29 & 2.37 \\
\hline C4 & 0.92 & 0.98 & 3.53 & 3.61 & 3.67 & 3.75 & 2.36 & 2.43 \\
\hline SEm \pm & 0.02 & 0.02 & 0.06 & 0.06 & 0.07 & 0.06 & 0.05 & 0.05 \\
\hline $\operatorname{LSD}(\mathbf{P}=\mathbf{0 . 0 5})$ & NS & 0.07 & 0.20 & 0.21 & 0.24 & 0.21 & 0.17 & 0.16 \\
\hline \multicolumn{9}{|c|}{ Nutrient management(N) } \\
\hline N1 & 0.84 & 0.88 & 3.26 & 3.33 & 3.37 & 3.44 & 2.09 & 2.17 \\
\hline $\mathbf{N} 2$ & 0.89 & 0.94 & 3.40 & 3.48 & 3.54 & 3.62 & 2.21 & 2.27 \\
\hline $\mathbf{N 3}$ & 0.90 & 0.97 & 3.44 & 3.52 & 3.59 & 3.65 & 2.30 & 2.38 \\
\hline SEm \pm & 0.01 & 0.02 & 0.04 & 0.05 & 0.05 & 0.05 & 0.03 & 0.03 \\
\hline $\operatorname{LSD}(P=0.05)$ & 0.04 & 0.05 & 0.13 & 0.14 & 0.16 & 0.14 & 0.08 & 0.09 \\
\hline
\end{tabular}


Int.J.Curr.Microbiol.App.Sci (2019) 8(3): 305-317

Table.3 Effect of crop establishment methods and nutrient management on dry matter accumulation $\left(\mathrm{g}\right.$ plant $\left.{ }^{-1}\right)$ at different growth stages of maize

\begin{tabular}{|c|c|c|c|c|c|c|c|c|}
\hline \multirow[t]{2}{*}{ Treatments } & \multicolumn{2}{|c|}{30 DAS } & \multicolumn{2}{|c|}{60 DAS } & \multicolumn{2}{|c|}{90 DAS } & \multicolumn{2}{|c|}{ At harvest } \\
\hline & 2013 & 2014 & 2013 & 2014 & 2013 & 2014 & 2013 & 2014 \\
\hline \multicolumn{9}{|c|}{ Crop establishment methods $(C)$} \\
\hline C1 & 96.4 & 97.85 & 121.9 & 123.66 & 194.6 & 196.59 & 216.6 & 215.58 \\
\hline $\mathrm{C2}$ & 98.0 & 99.69 & 127.9 & 129.62 & 199.8 & 201.68 & 222.8 & 221.68 \\
\hline C3 & 104.8 & 108.26 & 137.6 & 139.34 & 213.4 & 215.29 & 238.6 & 237.49 \\
\hline C4 & 111.2 & 111.54 & 141.6 & 143.37 & 219.7 & 221.48 & 243.0 & 241.81 \\
\hline SEm \pm & 2.05 & 1.99 & 2.67 & 2.59 & 3.99 & 3.95 & 4.39 & 4.59 \\
\hline $\operatorname{LSD}(\mathbf{P}=0.05)$ & 7.11 & 6.90 & 9.25 & 8.96 & 13.79 & 13.65 & 15.19 & 15.88 \\
\hline \multicolumn{9}{|c|}{ Nutrient management(N) } \\
\hline N1 & 97.5 & 100.34 & 126.0 & 127.81 & 197.2 & 199.03 & 218.9 & 220.74 \\
\hline $\mathbf{N} 2$ & 103.1 & 105.43 & 133.2 & 134.93 & 207.5 & 209.48 & 233.9 & 230.87 \\
\hline N3 & 107.2 & 107.25 & 137.6 & 139.25 & 215.9 & 217.78 & 238.0 & 235.82 \\
\hline SEm \pm & 1.32 & 1.52 & 1.93 & 1.81 & 3.07 & 2.84 & 4.76 & 3.16 \\
\hline $\operatorname{LSD}(P=0.05)$ & 3.95 & 4.57 & 5.78 & 5.42 & 9.20 & 8.51 & 14.26 & 9.47 \\
\hline
\end{tabular}


Table.4 Effect of crop establishment methods and nutrient management on N, P and $\mathrm{K}$ uptake $\left(\mathrm{kg} \mathrm{ha}^{-1}\right)$ by maize

\begin{tabular}{|c|c|c|c|c|c|c|c|c|c|c|c|c|}
\hline \multirow[t]{3}{*}{ Treatments } & \multicolumn{6}{|c|}{ 2013-14 } & \multicolumn{6}{|c|}{ 2014-15 } \\
\hline & \multicolumn{2}{|c|}{$\mathrm{N}$ uptake } & \multicolumn{2}{|c|}{ P uptake } & \multicolumn{2}{|c|}{ K uptake } & \multicolumn{2}{|c|}{$\mathrm{N}$ uptake } & \multicolumn{2}{|c|}{ P uptake } & \multicolumn{2}{|c|}{ K uptake } \\
\hline & Grain & stover & Grain & stover & Grain & stover & Grain & stover & Grain & stover & Grain & stover \\
\hline \multicolumn{13}{|c|}{ Crop establishment methods $(C)$} \\
\hline C1 & 63.398 & 63.836 & 9.702 & 7.429 & 13.864 & 71.048 & 65.935 & 65.71 & 10.222 & 7.824 & 14.540 & 72.855 \\
\hline $\mathrm{C} 2$ & 68.473 & 67.162 & 10.363 & 7.862 & 14.706 & 76.267 & 71.211 & 68.62 & 10.967 & 8.223 & 15.470 & 77.858 \\
\hline C3 & 88.733 & 75.722 & 13.402 & 9.185 & 18.609 & 93.646 & 92.527 & 80.50 & 14.323 & 10.056 & 19.579 & 96.869 \\
\hline C4 & 92.972 & 78.715 & 14.223 & 9.649 & 19.968 & 100.522 & 96.632 & 83.76 & 15.064 & 10.596 & 21.011 & 103.747 \\
\hline SEm \pm & 2.487 & 2.699 & 0.470 & 0.333 & 0.704 & 2.671 & 2.576 & 2.90 & 0.506 & 0.380 & 0.695 & 2.171 \\
\hline $\operatorname{LSD}(P=0.05)$ & 8.606 & 9.339 & 1.628 & 1.151 & 2.436 & 9.243 & 8.914 & 10.04 & 1.749 & 1.315 & 2.406 & 7.511 \\
\hline N1 & 59.441 & 66.019 & 10.453 & 7.837 & 14.885 & 77.870 & 62.061 & 69.03 & 11.093 & 8.415 & 15.672 & 80.120 \\
\hline N2 & 83.512 & 72.532 & 12.240 & 8.635 & 17.206 & 86.783 & 86.880 & 75.92 & 12.970 & 9.309 & 18.082 & 89.405 \\
\hline N3 & 92.229 & 75.525 & 13.075 & 9.121 & 18.270 & 91.459 & 95.788 & 79.00 & 13.867 & 9.800 & 19.196 & 93.972 \\
\hline SEm \pm & 1.823 & 1.934 & 0.324 & 0.238 & 0.442 & 1.929 & 1.895 & 2.03 & 0.368 & 0.261 & 0.450 & 1.976 \\
\hline $\operatorname{LSD}(P=0.05)$ & 5.465 & 5.7967 & 0.972 & 0.713 & 1.324 & 5.782 & 5.680 & 6.10 & 1.102 & 0.784 & 1.350 & 5.925 \\
\hline
\end{tabular}


The N, P and K uptake increased significantly with SSNM. The maximum values of $\mathrm{N}$ (207.24 kg/ha), P (32.42 kg/ha) and K (233.40 $\mathrm{kg} / \mathrm{ha}$ ) uptake were recorded under SSNM, which significantly increased 16.63, 46.69 and $41.12 \% \mathrm{~N}, \mathrm{P}$ and $\mathrm{K}$ under SSNM in compared to FFP, respectively. It might be due to application of balanced fertilization based on target yield resulting in higher total NPK uptake. A similar result was also reported by (Kumar at al. 2015), they revealed that the $\mathrm{N}, \mathrm{P}$ and $\mathrm{K}$ content and total uptake in maize (grain, stover) was significantly higher with SSNM which remained at par with RDF.

\section{References}

Aggarwal, P., Choudhary, K.K., Singh, A.K. and Chakraborty, D. 2006. Variation in soil strength and rooting characteristics of wheat in relation to soil management. Geoderma, 136, 353-363.

Anonymous, 2011. Vision 2030. Directorate of Maize Research, Pusa, New Delhi.

Bakht, J., Shafi, M., Jan, M.T. and Shah, Z. 2009. Influence of crop residue management, cropping system and $\mathrm{N}$ fertilizer on soil $\mathrm{N}$ and $\mathrm{C}$ dynamics and sustainable wheat (Triticum aestivum L.) production. Soil and Tillage Research, 104, 233-240.

Behera, U.K., Sharma, A.R. and Pandy, H.N. 2007. Sustaining productivity of wheatsoybean cropping system through integrated nutrient management practices on the Vertisols of central India. Plant and Soil, 297, 185-199.

Chopra, P. and Angiras, N.N. 2008. Effect of tillage and weed management on productivity and nutrient uptake of maize (Zea mays). Indian Journal of Agronomy, 53(1), 66-69.

Ghuman, B.S. and Sur, H.S. 2001. Tillage and residue management effects on soil properties and yields of rainfed maize and wheat in a subhumid subtropical climate. Soil and Tillage Research 58: 1-10.
Govaerts, B., Mezzalama, M., Sayre, K.D., Crossa, J., Lichter, K., Troch, V., Vanherck, K., De Corte, P., Deckers, J. 2008. Long-term consequences of tillage, residue management, and crop rotation on selected soil micro-flora groups in the subtropical highlands. Applied Soil Ecology 38: 197-210.

Griffith, D.R., Kladivko, E.J., Mannering, J.V., West, T.D. and Parsons, S.D. 1986. Longterm tillage and rotation effects on corn growth and yield in high and low organic matter poorly drained soils. Agronomy Journal 80: 559-605.

Jat, M.L., Saharawat, Y.S. and Gupta, R. 2011. Conservation agriculture in cereal systems of south Asia: Nutrient management perspectives. Karnataka J. Agric. Sci., 24(1):100-105.

Kumar, V., Singh, A.K., Jat, S.L., Parihar, C.M., Pooniya, V. and Sharma, S. 2015 Nutrient uptake and fertilizer-use efficiency of maize hybrids under conservation agriculture with nutrient expert based SSNM practices. Indian Journal of Agronomy, 36(2), 160-166.

Kumar, V., Singh, A.K., Jat, S.L., Parihar, C.M., Pooniya, V., Sharma, S. and Singh, B. 2014. Influence of site-specific nutrient management on growth and yield of maize (Zea mays) under conservation tillage. Indian Journal of Agronomy, 59(4), 657660.

Kumar, Vivak., Saharawat, Y.S., Gathala, M.K., Jat, A.S., Singh, S.K., Chaudhary, N. and Jat, M.L. 2013. Effect of different tillage and seeding methods on energy use efficiency and productivity of wheat in Indo-Gangetic plains. Field Crop Research, 142, 1-8.

Lal, R., 1997. Residue management, conservation tillage and soil restoration for mitigating greenhouse effect by $\mathrm{CO}_{2}{ }^{-}$ enrichment. Soil Tillage Research 43: 81107.

Nema, H.R., Sharma, S.K. and Verma, O.P. 1996. Effect of surface drainage on soil physical environment and maize growth in vertisol of central India. New Botanist, 
23(1-4), 175-183.

Patra, A.K., Chhonkar, P.K. and Khan, M.A. 2004. Nitrogen loss and wheat (Triticum aestivum) yields in response to zero-tillage and sowing time in a semi-arid tropical environment. Journal of Agronomy and Crop Science, 190, 324-331.

Prasad, R., Shivay, Y.S., Kumar, D. and Sharma, S.N. 2006. Learning by doing exercise in soil fertility (A practical manual for soil fertility), Division of Agronomy, Indian Agricultural Research Institute, New Delhi, pp. 68.

Ram, H. 2006. Micro-environment and productivity of maize-wheat and soybeanwheat sequences in relation to tillage and planting systems. Ph.D. Thesis, Punjab Agricultural University, Ludiana, Punjab, India.

Saharawat, Y.S., Ladha, J.K., Pathak, H., Malik, R.K., Gathala, M. and Gupta R.K. 2011. Validation of InfoRCT model for resource conserving technologies in rice-wheat system on productivity, income and environment. Journal of Soil Science and Environment. Management 3: 9-22.

Sain Dass, Singh, K.P. and Yadav, V.K. (2007). Present status and potential of maize hybrids in enhancing the productivity. National Conference on "Doubling Maize Production" organized by IFFCO Foundation, ICAR, DMR, DAC and IFFCL at New Delhi, May 8-9, 2007. pp. 13-19.

Scopel, E., Findeling, A., 2001. Conservation tillage impact on rainfed maize production in semi-arid zones of western Mexico. Importance of runoff reduction. In: Conference Proceeding of the I World Congress on Conservation Agriculture. Madrid, 1-5 October.

Singh, R., Sharma, A.R., Dhayani, S.K. and Dube, R.K. 2011. Tillage and mulching effects on performance of maize (Zea mays)-wheat (Triticum aestivum) cropping system under varying land slopes. Indian Journal of Agricultural Sciences, 81(4), 330-335.

Singh, R., Sharma, A.R. and Behera, U.K. 2007. Tillage and crop establishment practices for improving productivity of maize (Zea mays) under different weed control methods. Indian Journal of Agricultural Sciences, 77(11), 731-737.

Timsina, J., Jat, M.L. and Majumdar, K. 2010. Rice-maize systems of South Asia: current status, future prospects and research priorities for nutrient management. Plant and Soil 335:65-82.

Tolk, J.A., Howell, T.A. and Evett, S.R. 1999. Effect of mulch, irrigation and soil type on water use and yield of maize. Soil and Tillage Research, 50, 137-147.

Ussiri, D.A.N. and Lal, R. 2009. Long-term tillage effects on soil carbon storage and carbon dioxide emissions in continuous corn cropping system from an alfisol in Ohio. Soil and Tillage Research 104: 3947.

Wilhelm, W.W., Bouzerzour, H. and Power, J.F. 1989. Soil disturbance- residue management effect on winter wheat growth and yield. Agronomy Journal, 81, 581-588.

Wright, A.L., Hons, F.M. and Matocha, J.E., 2005. Tillage impacts on microbial biomass and soil organic carbon and nitrogen dynamics of corn and cotton rotations. Applied Soil Ecology 29: 85-92.

Yadav, D.S., Shukla, R.P., Sushant and Kumar, B. 2005. Effect of zero tillage and nitrogen level on wheat (Triticum aestivum) after rice (Oryza sativa). Indian Journal of Agronomy, 50(1), 52-53.

Yadav, R.L. 2003. Assessing on-farm efficiency and economics of fertilizer $\mathrm{N}, \mathrm{P}$ and $\mathrm{K}$ in rice-wheat systems of India. Field Crops Research 81: 39-51. 


\section{How to cite this article:}

Lakhapati Singh, U.P. Singh and Singh, M.K. 2019. Effect of Crop Establishment and Nutrient Management on Growth Parameter and Nutrient Uptake in Maize Wheat System of Northern Plains of IGP. Int.J.Curr.Microbiol.App.Sci. 8(03): 305-317. doi: https://doi.org/10.20546/ijcmas.2019.803.038 